\title{
LIBERTAD DE EXPRESIÓN: ¿DERECHO ILIMITADO SEGÚN EL TEDH? DEL DISCURSO DE ODIO AL CRIMEN DE ODIO
}

\author{
David Martín Herrera
}

SuMARIO: 1. BREVE ACERCAMIENTO AL CONCEPTO DE «HATE CRIME».

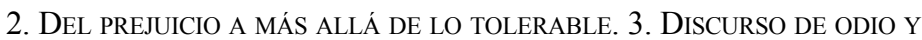
DERECHO INTERNACIONAL DE LOS DERECHOS HUMANOS. ¿ES POSIBLE DETECTAR EL «HATE SPEECH»? 4. ¿PUEDE EJERCERSE LA LIBERTAD DE EXPRESIÓN DE MANERA ILIMITADA? 5. CASOS OTEGUI Y FÉRET. El DISCURSO DEL ODIO SEGÚN LOS TRIBUNALES EUROPEOS. 5.1. Otegui Mondragón vs. España: controversia, «chilling effect» y obstinación. 5.2. Estado español y jurisprudencia de Estrasburgo. 5.3. Féret vs. Bélgica: TEDH y «hate speech» en politica. 6. ConClusiones. 7. BiBLIOGRAFÍA.

«Podemos hacer del problema de los delitos de odio tan grande o pequeño como deseemos manipular su definición.»

Jacobs \& Potter

\section{BREVE ACERCAMIENTO AL CONCEPTO DE «HATE CRIME»}

Bajo el seudónimo «hate crimes», comprenderían aquellos tipos delictivos en los que el móvil es causa de la intolerancia hacia el diferente.

A priori puede resultar una materia básica y aparentemente superada, al estar -bajo influencia del derecho internacional de los derechos humanos- recogida en la práctica totalidad de los códigos penales de los Estados miembros de la Unión Europea <en el caso español en sus artículos 22.4, 510, 511, 512 y 607>1.

${ }^{1}$ De forma comparada, el tipo de violencia contra personas o grupos caracterizados por determinados caracteres queda recogido en la práctica totalidad de los Códigos pena- 
Como veremos (pese a ser diversas las definiciones y aproximaciones aportadas por la doctrina y las instituciones), en torno al concepto de los delitos de odio, a día de hoy, ninguna de ellas ha sido adoptada de manera uniforme, y teniendo presente el grueso de tipos delictivos, resulta mínima la jurisprudencia al respecto.

Caracterizados por una extrema y terrible brutalidad causan per se, un efecto estigmatizador en la víctima que unido a un impacto psicológicoemocional, produce ad quo damnum, consecuencias aún superiores a las generadas en las víctimas de crímenes comunes. A ello debemos añadir, que cualquier tipo de delito cometido por odio lleva aparejado un mensaje de alarma hacia el resto de miembros de la comunidad a la que pertenece la víctima, intimidando, como si de una pandemia se tratara.

Entre los diferentes estudios encontrados, es de destacar el del Bureau of Justice Assistence (BJA) del Departamento de Justicia de los Estados Unidos de América (USA).

De manera contradictoria apuntaba en la década de los noventa el BJA, que los delitos de odio eran «un duro y reciente fenómeno», que de manera análoga se asociaba con la historia. Identificando como tal, entre otros: la persecución de los cristianos en el imperio romano, la solución final a los judíos por los nazis, la limpieza étnica en Bosnia o el genocidio de Ruanda ${ }^{2}$. Sostiene el BJA que mientras en USA el término «hate crime» resulta el más utilizado para describir un ataque de un blanco hacia un afroamericano, el mismo suceso sería conocido en Alemania como «violencia de extrema derecha», o «violencia xenofóbica» en el Reino Unido y Francia.

Según esta institución, los delitos de odio son «crímenes que manifiestan evidencias o prejuicios basados en la raza, religión, orientación sexual, ori-

les europeos. En el caso español, castiga con penas de uno a tres años a los que «provocaren a la discriminación, al odio o a la violencia contra grupos o asociaciones, por motivos racistas, antisemitas u otros referentes a la ideología, religión o creencias, situación familiar, la pertenencia de sus miembros a una etnia o raza, su origen nacional, su sexo, orientación sexual, enfermedad o minusvalía...» Vid. Artículo 510.2, Ley Orgánica 10/1995, de 23 de noviembre, del Código Penal. En comparación, el artículo 196.2 del Código penal de la República Checa, castiga con tres años de prisión a quien use violencia contra persona o grupo de personas o amenacen gravemente, por motivos de ideología política, nacionalidad, raza, religión o creencia. Por su parte el artículo 283 del Código penal austriaco, castigaría la incitación a la violencia con penas de dos años, a los que, amenacen el orden público o inciten a acciones hostiles contra la iglesia o comunidades religiosas existentes en Austria o contra grupos definidos por su afiliación tales como la iglesia o comunidad religiosa, un grupo racial, una persona, un grupo étnico o un Estado. Nótese que el ámbito de protección difiere en cada uno de los tres ejemplos expuestos, marginando cada cual a grupos o personas caracterizados por diferentes rasgos o conexiones a las mencionadas.

${ }^{2}$ Vid. AA.VV., «A Policymaker's Guide to Hate Crimes», Bureau of Justice Assistance, Washington, (1997). 
gen étnico, incluyendo en su caso los asesinatos, homicidios no negligentes, violaciones forzadas, asaltos agravados, asaltos simples, intimidaciones, incendios intencionados y la destrucción daños o vandalismo a la propiedad $\iota^{3}$.

De su lectura literal, comprobamos que los delitos de odio quedan circunscritos dentro de los casos en los que el prejuicio sea consecuencia de la raza, religión, orientación sexual o etnia, quedando así marginales aquellos otros sucesos en los que el prejuicio tenga otras características. A lo tímido de la definición se le añade la contradicción en el uso de los términos dentro del propio BJA dado que el Federal Bureau of Investigation (más conocido como FBI), promueve el empleo del término «bias crime» (crímenes motivados por prejuicio) en lugar del concepto de delitos de odio, para asegurar la homogeneidad en los informes relacionados con los hate crime. Entendiendo que aquellos corresponden con aquellas «actitudes u opiniones negativas preformadas hacia grupos de personas, basadas en su raza, religión, discapacidad, orientación sexual u origen nacional o étnico». Nótese que, de las dos definiciones aportadas por la misma Institución, la del FBI, amplía la protección al grupo de discapacitados y nacionales ${ }^{4}$.

Aún más paradójico resulta que sea el propio FBI, el que reconoce que existen numerosos tipos de prejuicios, algunos de ellos por cuestiones de raza, religión, discapacidad, orientación sexual, origen nacional o étnico, pero también otros «biases» dirigidos contra: los ricos, gente pobre, hombres con el pelo largo, barbudos, personas que se visten de forma rara, fumadores, alcohólicos, personas con enfermedades tales como el SIDA, bandas de motociclistas, rockeros..., dejando aún en el olvido las ideologías 5 .

Pese a parecer amplio el reconocimiento, tal y como apuntaba Goodey, las legislaciones y programas de delitos de odio tienden a ampliar el rango de reconocimiento del impacto de los delitos de odio, entre otros, posiblemente porque al igual que el crimen, el odio también va mutando. Es por ello por lo que nos resulta contradictorio que reconociendo el propio FBI, la suma amplitud de este fenómeno, avale que la «Enabling Act» y sus enmiendas, limi-

3 Según la «Hate Crimes Statist Act de 1990», hate crimes son: «crimes that manifest evidence of prejudice based on race, religion, sexual orientation, or ethnicity, including where appropriate the crimes of murder, non-negligent manslaughter, forcible rape, aggravated assault, simple assault, intimidation, arson and destruction, damage or vandalism of property». El propio BJA, apunta que la presente definición es la mayormente aceptada en USA, aunque algunos Estados disponen de otras, así «Connecticut», incluye a las personas discapacitadas como posibles víctimas; «Illinois», incluye el color, la creencia, el linaje, y la discapacidad mental y física; «Rhode Island' s» incluye discapacidad y género y «Pennsylvania» no reconoce la orientación sexual. Vid. Ibídem, p. 2.

4 Vid. Ibídem, p.2.

5 Vid. U.S. Department of Justice. Federal Bureau of Investigation, «Hate Crime Data Collection Guidelines. Uniform Crime Reporting», (1999). 
ten las actuaciones en las investigaciones únicamente a supuestos en los que estén involucradas cuestiones de raza, religión, orientación sexual o etnia ${ }^{6}$.

En esta línea, la Oficina para las Instituciones Democráticas y los Derechos Humanos (en adelante ODIHR) presentó en 2005 una definición de trabajo, en la que definía un delito de odio como: «(A) cualquier infracción penal, incluyendo infracciones contra las personas o las propiedades, donde la víctima, sus bienes o el objetivo son elegidos por su real o asimilada conexión, afiliación, apoyo o pertenencia a un grupo definido en la parte B; (B) un grupo debe estar basado en una característica común de sus miembros, tal como su real o perceptiva raza, nacional o étnico origen, lenguaje, color, religión, sexo, edad, minusvalía mental o física, orientación sexual u otro factor similar» ${ }^{7}$.

Con esta definición la ODIHR ambiciona al menos en su ámbito de trabajo, tratar de homogeneizar determinadas normas penales como base para una futura regulación común que permita acotar y atajar conjuntamente este tipo de sucesos. Sin embargo, observamos nuevamente que quedan desterrados del paraguas protector, aquellos grupos marginados o discriminados que se identifiquen con otro factor similar, que sea real o percibido por su ofensor, resultando así, un mero cajón de sastre de imposible operativa policial e inimaginable aplicación procesal.

Por otro lado, para la Agencia de Derechos Fundamentales de la Unión Europea (en adelante FRA), la historia de Europa es una larga historia de delitos de odio e intolerancia en la que sus países comparten historias empapadas de esclavitud, colonialismo, inmigración y dictaduras que sirven para informarnos «cómo y por qué cada país responde a los delitos de odio en una dirección determinada», comprendiéndose así, que «no haya una única definición legal o social de los delitos de odio o crímenes racistas en Europa» ${ }^{8}$.

Apreciamos aquí, que no se trata únicamente de un problema de definición legal, sino que además, parece estar anclado en prejuicios histórico-culturales directamente conexionados con la situación social del momento y del lugar.

${ }^{6}$ The types of bias to be reported to the FBI's UCR Program are limited to those mandated by the enabling Act and its subsequent amendments. Vid. Ibídem, p.1 y ss.

7 Vid. Goodey, J. \& AromaA, K., Hate Crimes. Papers from the 2006 and 2007 Stockholm Criminology Symposiums, Ed. Criminal Justice Press, Helsinki, 2007, p. 5.

${ }^{8}$ Las interpretaciones y percepciones de un fenómeno de costoso reconocimiento institucional resultan diferentes per se, más aún lo serán sí en la práctica, determinados Estados miembros de la UE, «have tended to focus on certain manifestations of hate; [...] racial, ethnic and religious hatred (notably anti-Semitism), and less so to hate with respect to sexuality, disability, new manifestations of religious intolerance, and gender. In comparation with current US hate crime laws and programmes, which tend to be wide-ranging in their recognition of hate crime as impagting on many different social groups, European legislation and recognition of hate crime is relatively narrow and under-developed. Vid. GOODEY, J., «Racist Crime in the European Union: Historical Legacies, Knowledge Gaps, and Policy Development» en: Goodey, J. \& AromaA, K., op. cit., p.16 y ss. 


\section{DEL PREJUICIO A MÁS ALLÁ DE LO TOLERABLE}

A las especiales dificultades a la hora de delimitar que grupos deben ser amparados bajo el enclave de los delitos de odio, se adiciona la inverosímil determinación de: qué tipo de conductas, qué expresiones, qué acciones, o qué ideologías han de ser consideradas prejuiciosas y por tanto discriminatorias.

En esta línea apuntan Jacobs \& Potter en relación a la propia definición de los delitos de odio, cuando acertadamente aseveran que se trata de un concepto de difícil determinación debido a la imposible delimitación de entre otros, los límites del prejuicio, los tipos de prejuicios que podrían ser albergados dentro de la normativa de los delitos de odio, qué tipos de crímenes atribuibles a prejuicios podrían categorizarse como delitos de odio, y cómo de fuerte debe de ser la conexión entre el prejuicio del perpetrador y su conducta criminal. Siguiendo esos parámetros, la mesura del prejuicio diferirá en función del clima social y político del lugar, resultando un fenómeno más o menos grueso en función de su percepción.

Tal vez por ello, vaticinaban que «usar los prejuicios y conducir a los criminales como testigos de las intolerancias de la sociedad o como indicador de la incivilización en las relaciones intergrupales, resultaría ser un grave error». Asegurando que al ser el término «hate crimes», de reciente construcción social, está enfocado hacia aquellas conductas criminales motivadas por ideas preconcebidas y focalizadas más en la psicología del criminal que en la propia conducta criminal ${ }^{9}$, enfatizando de forma acertada, que en función de la amplitud que deseemos dar al término prejuicio, «podremos hacer del problema de los delitos de odio tan grande o pequeño como deseemos manipular su definición ${ }^{10}$.

Sin embargo pese a ser este un enfoque más o menos novedoso, no podemos obviar que muchos de esos prejuicios son transmitidos de generación en

${ }^{9}$ Según exponen estos autores, la concienciación individual en USA, varía según sean las personas de conscientes con sus propios prejuicios y de la propia voluntad de admitirlo. While only a small minority espouse their prejudices as ideologies, most deny that they hold any prejudices, sometimes in good faith and sometimes because they are ashamed of them. En relación al racismo, se ha hecho cada vez más inaceptable en las últimas décadas, «Americans often deny and repress their prejudices». Sin embargo, la pregunta lanzada respecto a porque algunas víctimas deben ser mayormente protegidas que otras, nos inunda aún más en el mar de confusiones respecto a la percepción y determinación del fenómeno. There are many different types of prejudices that might qualify for hate crime designation. Some civil rights and affirmative action legislation speaks in term of "protected groups», but this does not easily apply in the hate crime context because when it comes to crime, all victims are a protected group. Why should some victims be considered more protected than others? Vid. JaCoBS, J.B. Y PotTER, K., Hate Crimes. Criminal Law and Identity Politics, Ed. Oxford University Press, New York, 1998, p. 3 y ss.

${ }_{10}$ «In other words, we can make the hate crime problem as small or large as we desire by manipulating the definition». Vid. Ibídem, p.28. 
generación a través de los grupos sociales, por la propia tradición cultural, a través de la religión, de los medios de comunicación, etc. Resultando algunos socialmente aceptados, como el antifascismo, y otros rechazados como la misoginia. En cualquier caso, si que es importante considerar el enfoque hacia aquellas conductas criminales motivadas por ideas preconcebidas y focalizadas, dado que, equiparar una idea en abstracto -tal y como indican esos autores- con una conducta criminal que no ha sido perpretada, desbordaría cualquiera de los principios por los que se rige el Derecho penal.

De forma análoga, encontraríamos dificultades a la hora de delimitar qué conductas prejuiciosas han de considerarse dentro de los márgenes de los delitos de odio y cuáles no. Así el espectrograma, resultaría tanto más amplio cuanto mayor sean los tipos delictivos inmersos, de manera que si tan solo consideramos incursos en nuestra definición los tipos delictivos graves (agresiones y daños a la propiedad), el resultado será cuantitativamente inferior al que obtendríamos si consideramos también inmersos en ese tipo de conductas, los actos previos o la antesala de las agresiones motivadas por el odio. Nos referimos aquí, no al mero pensamiento en abstracto, sino, a todas aquellas manifestaciones de hostilidad hacia determinadas personas o grupos, tales como actos vandálicos, grafitis, la propaganda y especialmente el temido discurso de odio «hate speech» que trataremos de analizar.

Per se, resulta factible encontrar infinidad de obstáculos legislativos, y no resultan en cuantía inferior los obstáculos procesales que se les presentarán a los Tribunales que desconozcan, a priori, los límites y la praxis a seguir en función del tipo de conducta criminal perpetrada, sin poder determinar si la causa, fue completamente, predominantemente o parcialmente, perpetrada por prejuicio; y poder determinar si con tales presupuesto tal conducta llegaría a ser considerada un delito de odio.

La práctica jurídica en países del área de la common law (donde como hemos indicado, se ha venido tipificando y aplicando mayoritariamente este tipo de crímenes), nos demuestra que cualquier fisura en las definiciones desemboca en sentencias divididas cuando no dispares. Así en controvertida sentencia que versaba sobre agresiones múltiples contra persona que había sido condenada previamente por pedofilía, la New South Wales Court of Criminal Appeal, consideró que los pedófilos resultaban ser un grupo de personas contra los que se perpetraban crímenes motivados por las específicas características que les identificaban, resultado in fine, sujetos afectos de la especial protección jurídica que les confería el derecho penal especial de los «hate crimes», aplicándose en consecuencia a sus agresores la agravante discriminatoria correspondiente a la pena final ${ }^{11}$.

${ }^{11}$ En un controvertido caso en el que cierta persona incendió en dos diferentes ocasiones el inmueble de su vecino, la Juez acabo sentenciando con la aplicación de agravante a la pena final, al considerar evidencias de que ambos incendios habían sido perpetrados 


\section{DISCURSO DE ODIO Y DERECHO INTERNACIONAL DE LOS DERECHOS HUMANOS. ¿ES POSIBLE DETECTAR EL «HATE SPEECH»?}

«Toda propaganda en favor de la guerra estará prohibida por la ley. Toda apología al odio nacional, racial o religioso que constituya incitación a la discriminación, la hostilidad o la violencia estará prohibido por la ley». Sin lugar a dudas, la realidad fáctica del artículo 20 del Pacto Internacional de Derechos Civiles y Políticos (PIDCP), parece distar bastante de su lex lata de 1966.

Tal y como indicábamos anteriormente, el concepto de delitos de odio no es un tipo de crimen afecto únicamente a la hipermodernidad, los mismos, se han venido cometiendo a lo largo de la historia. Si bien es cierto, que las etapas descolonizadoras y la globalización han venido favoreciendo su incremento exponencial ${ }^{12}$. Consecuencia o no, diversos han sido los tratados internacionales que han tratado de frenar este tipo de sucesos, sin haber obtenido una respuesta apropiada en las diferentes legislaciones internas de sus Estados parte.

Así la Convención Internacional sobre la Eliminación de todas las formas de Discriminación Racial (CIEDR), mandaba ya a los Estados parte en 1965,

en parte, porque el agresor consideraba que su víctima era pedófilo. La Corte consideró que tal motivación debía ser enmarcada dentro del concepto de los delitos de odio, al haber sido perpetrados por la espeluznante «orientación sexual» de la víctima. Según Mason, el reconocimiento de tal género - bajo la cobertura de los delitos de odio- entre otros, es causa de la deficiente formación de los Tribunales. Para este autor, «the provisión has the potential to be applied to convictions for offences motivated by hatred or perjuice towards any identificable group of people, e.g. politicians, lawyers, judges, cyclists, academics, rapists, enviromentalists, for wheel-drive owners, and chocolate lovers.». Vid. MAson, G., «Hate crime in Australia: Are they achieving goals?», Ed. National Judicial College of Australia, 2010, p. 16 y ss.

12 Entre otros apunta Giménez-Salinas que los intentos de globalización de todos los imperios y colonizaciones, se llevaron a cabo desde la anulación de la diferencia y la imposición de una homogeneidad arbitraria, todo lo cual aumentaba el resentimiento, la lucha de contrarios, y ha imposibilitado anular la violencia entre grupos. Vid. GIMENEZSalinas i Colomer, E., Román Maestre, B., García Solé, M., «Sociedad Abierta y Delitos de Odio en la Era de la Globalización», Eguzkilore: Cuaderno del Instituto Vasco de Criminología, Universidad Ramón Lluch, Barcelona, Vol. 17, San Sebastián, 2003, p.121 y ss. Sabemos que el siglo XX fue el del advenimiento de los movimientos globalizantes. No sólo en lo económico y lo político, sino en lo cultural al intentar la uniformidad ideológica. Pero mientras las fronteras geopolíticas se hicieron laxas para algunos, otras fronteras, especialmente las culturales, se endurecieron. La tensión vino entonces a concentrarse en las consecuencias de los desplazamientos mundiales y en el renacimiento de los racismos. Vid. Lolita Aniyar de Castro, «Los Crímenes de Odio: Discurso Político y Delincuencia Violenta en Venezuela. El Respeto a las Diferencias y el Rol de la Criminología Crítica en Venezuela en los Inicios del Siglo XXI», Capítulo Criminológico, Vol. 36, Núm. 2, (2008). 
condenar toda propaganda y organizaciones inspiradas en ideas o teorías basadas en la superioridad de una raza o de grupos de personas de determinado color u origen étnico, que pretendieran justificar o promover el odio y la discriminación racial; entre otros, exhortaba la punibilidad de «toda difusión de ideas basadas en la superioridad o en el odio racial, cualquiera que sea su forma» ${ }^{13}$.

Por su parte, la Convención Americana sobre los Derechos Humanos (CADH), ad hoc, siguiendo las directrices enunciadas previamente por el PIDCP, encomendaba la prohibición de «toda propaganda en favor de la guerra y toda apología del odio nacional, racial o religioso que constituyan incitaciones a la violencia o cualquier otra acción ilegal similar contra cualquier persona o grupo de personas, por ningún motivo» ${ }^{14}$. Dichas directrices no parecieron incidir en la redacción del Convenio Europeo de Derechos Humanos (CEDH), que a prima facie concedió un especial valor al derecho a la libertad de expresión, considerada como uno de los Derechos fundamentales en los que se asientan la mayoría de los sistemas constitucionales europeos $^{15}$. La claridad del texto americano en relación a los límites a la libertad de expresión, quedó empañada en el texto europeo donde confirió limitar la libertad de expresión, en los supuestos en los que una ley nacional estableciera medidas para salvaguardar la «seguridad nacional, la integridad territorial o seguridad pública, la defensa del orden y la prevención del delito, la protección de la salud o de la moral, la protección de la reputación o de los derechos ajenos, para impedir la divulgación de informaciones confidenciales o para garantizar la autoridad y la imparcialidad del poder judicial» ${ }^{16}$.

La vaguedad con la que el legislador europeo redactó el artículo $10 \mathrm{CEDH}$ dejó lugar a todo tipo de interpretaciones, dado que mediante un giño a la

${ }_{13}$ Vid. Resolución 2106 A (XX) de la Asamblea General de las Naciones Unidas de 21 de diciembre de 1965. Convención Internacional sobre la Eliminación de todas las formas de Discriminación Racial, artículo 4.

14 Vid. Convención Americana sobre Derechos Humanos, Pacto de San José de 22 de noviembre de 1969, artículo 13.5 .

15 Por poner varios ejemplos en Derecho constitucional comparado, el conocido artículo 20 de la Constitución española de 1978 dedicado a la libertad de expresión, viene enclavado dentro del Capítulo dedicado a los Derechos y Libertades. El mismo artículo en la Constitución de la República italiana de 1947, viene inserto bajo el epígrafe 21 de la Parte Primera, dedicada a los Derechos y Deberes de los Ciudadanos. Por su parte en la Constitución de la República Federal alemana de 1945, la libertad de expresión viene recogida en el artículo 5, dentro del Capítulo I, dedicado a los Derechos Básicos. Y por poner el ejemplo de la paradigmática Constitución abierta de la Confederación helvética, el artículo 16 dedicado a la libertad de expresión, viene recogido desde la reforma de 18 de abril de 1999, bajo el Título II, que está dedicado a los Derechos Fundamentales, Derechos Civiles y Objetivos Sociales.

16 Vid. Convenio Europeo de Derechos Humanos de 4 de noviembre de 1950, artículo 10 . 
libertad de expresión y en especial la de los medios de comunicación, omitió albergar bajo tan emblemático convenio y sus sucesivos protocolos las pautas marcadas por las anteriores convenciones expuestas ${ }^{17}$. La misma vaguedad legislativa se dió aún más acusada en la Carta de Derechos Fundamentales de la Unión Europea, donde sus legisladores ni siquiera dejaron en manos de una ley especial, la limitación los discursos extremos, derribando eso si, las fronteras que la ley pudiera establecer dentro de la Unión ${ }^{18}$.

\section{4. ¿PUEDE EJERCERSE LA LIBERTAD DE EXPRESIÓN DE MANERA ILIMITADA?}

Reconocida como uno de los logros en la lucha por los derechos civiles del siglo XX, la libertad de expresión, ha sido internacionalmente amparada bajo la cobertura de los artículos 18 y 19 de la Declaración Universal de los Derechos Humanos ${ }^{19}$ y especialmente bajo el artículo 19 del PIDCP ${ }^{20}$. Con-

${ }_{17}$ Para poder encontrar un amparo legal frente al abuso o el mal uso de la libertad de expresión en supuestos en los que se trate de camuflar el discurso de odio en el ejercicio de la misma. El juez europeo deberá buscar refugio legislativo en la prohibición del abuso del derecho del artículo 17 de la CEDH. Del mismo modo, la prohibición de discriminación del artículo 14 de la CEDH análogamente ampararía las situaciones en las que determinados discursos y aún más, acciones, se dirijan contra las personas caracterizadas por su diferencia. Sin embargo, al igual que nos resulta caprichosa la forma retórica con la que el legislador europeo promulga el uso de la libertad de expresión y los delegados límites a la misma, en relación a la seguridad nacional, integridad territorial, seguridad pública, prevención del delito, protección de la salud o de la efímera moral (nos evoca esta última alocución a las temerosas e impunes Convenciones Antidrogas que iniciaron su andadura bajo el lema de la preocupación por «la salud y moral de la humanidad»). Resulta más que curioso que el legislador europeo haya descuidado su caligrafía a la hora de dibujar los límites al uso ilegítimo de la libertad de expresión y no solo por los referentes de otras convenciones internacionales anteriormente expuestas, sino mayormente por la propia trágica historia asociada al discurso del odio que caracteriza a Europa. Nos atrevemos a decir que el uso de la libertad de expresión queda en el CEDH tan irregularmente redactada como quedó en la Carta de Banjul. Vid. Convenio Europeo de Derechos Humanos de 4 de noviembre de 1950, artículos 10,2, 14 y 17. Vid. Carta Africana de Derechos Humanos de 27 de julio de 1981, artículo 9.2.

18 Vid. Carta de los Derechos Fundamentales de la Unión Europea, DOCE C/364 de 18.12.2000, Artículo 11, p. 11.

19 El artículo 19 de la Declaración Universal de Derechos Humanos apunta que «todo individuo tiene derecho a la libertad de opinión y de expresión; este derecho incluye el de no ser molestado a causa de sus opiniones, el de investigar y recibir informaciones y opiniones, y el de difundirlas, sin limitación de fronteras, por cualquier medio de expresión.»

${ }^{20}$ Según la redacción del artículo 19.2 PIDCP, «este derecho comprende la libertad de buscar, recibir y difundir informaciones e ideas de toda índole, sin consideración de fronteras, ya sea oralmente, por escrito o en forma impresa o artística, o por cualquier otro procedimiento de su elección.» 
fiere así el Derecho internacional de los derechos humanos una especial protección a la difusión de ideas y pensamientos, amparando con el mismo grado de seguridad jurídica, aquellos tipos de expresiones, informaciones, ideas de tipo disidente, que hieren, molesten e incluso alarmen, tal y como lo ha venido reconociendo ampliamente la jurisprudencia, pero siguiendo los límites que el propio Derecho internacional establece especialmente en el artículo 20 del PIDCP ${ }^{21}$.

Entre el orgullo y el ejemplo, la Comisión Interamericana de Derechos Humanos (CIDH) sostiene que el sistema interamericano de los derechos humanos, es «probablemente el sistema internacional que da mayor alcance y rodea de mejores garantías a la libertad de pensamiento y expresión $»^{22}$. Buena prueba de ello es la lectura del propio artículo 13 del CADH por el que, inter alia en un solo precepto, se da cabida a los mandatos de los artículos 19 y 20 del PIDCP, pendientes de completar entre otros, por el CEDH.

Pero la protección reservada a la libertad de expresión no resulta infinita bajo el CADH, y es la propia jurisprudencia de la Corte Interamericana de Derechos Humanos la que establece apoyándose en la jurisprudencia de otros Tribunales internacionales como el Tribunal Europeo de Derechos Humanos $(\mathrm{TEDH})$, que no se trata de un «derecho absoluto» ${ }^{23}$, reconociendo que cierto tipo de discursos resultan antagónicos a la doctrina del derecho internacional de los derechos humanos.

Quedan así excluidos de la protección de la libertad de expresión del artículo $13 \mathrm{CADH}$, «toda propaganda en favor de la guerra y toda apología

${ }^{21}$ En sus epígrafes uno y dos, el PIDCP dibuja los límites a la libertad de expresión de forma pragmática, afirmando que «toda propaganda en favor de la guerra estará prohibida por la ley. Toda apología del odio nacional, racial o religioso que constituya incitación a la discriminación, la hostilidad o la violencia estará prohibida por la ley.» Vid. Resolución 2200 A (XXI) de la Asamblea General de las Naciones Unidas, de 16 de diciembre de 1966. Pacto Internacional de Derechos Civiles y Políticos, artículo 20.

22 Vid. Organización de los Estados Americanos. Comisión Interamericana de Derechos Humanos, «Informe anual de la Comisión Interamericana de Derechos Humanos 2008. Informe de la Relatoría Especial para la Libertad de Expresión», Volumen III. Secretaría General de los Estados Americanos, Washington, (2009), p. 119.

${ }^{23}$ Entre otros, en caso Kimel vs. Argentina, la Corte Interamericana de Derechos Humanos estimó que la libertad de expresión sin llegar a ser un derecho absoluto, la propia Convención que prohíbe la censura, prevé la posibilidad de exigir responsabilidades ulteriores por su ejercicio abusivo, estimando no contraria a la Convención, «cualquier medida penal a propósito de la expresión de informaciones u opiniones» que sea analizada con especial cautela, recayendo la carga de prueba, «en quien formula la acusación», todo ello -observando los movimientos en la jurisprudencia de otros Tribunales, entre otros los del TEDH - se promueva con racionalidad y equilibrio, la protección que merecen los derechos en aparente pugna sin lesionar «las garantías que requiere la libre expresión como baluarte del régimen democrático». Vid. Corte Interamericana de Derechos Humanos, Caso Kimel vs. Argentina, Sentencia de 2 de mayo de 2008, Epígrafes, 54 y 78. 
del odio que constituya incitación a la violencia, tal y como se establece en su epígrafe quinto. Del mismo modo, quedaría excluido de la protección $a b$ initio del mencionado precepto, todo acto de «incitación directa y pública al genocidio no estableciendo nada respecto a la discutida negación del genocidio, limitando por último, todo acto relacionado con la «pornografía infantil».

Como dato importante apunta la CIDH que la legitimidad de las restricciones a la libertad de expresión, deberán de ser aplicadas tanto a las leyes que las establecen, como a las «decisiones y actos administrativos, judiciales, policivos o de cualquier otra índole que les materializan [sic.], es decir, a toda manifestación del poder estatal $\rangle^{24}$, tal y como lo establece la jurisprudencia ${ }^{25}$.

Nos evocan aquí, que no solo las expresiones y actos de odio son ejecutados por los intolerantes, y que, a fortiori, en múltiples ocasiones son las propias Instituciones las que incitan y ejecutan el odio o hacen un uso indebido de las restricciones impuestas por las propias convenciones. Entre otras, por ejemplo, las prohibiciones que el gobierno brasileño hizo contra diversas manifestaciones convocadas en varias ciudades por el movimiento global «Marijuana March», las mismas, fueron decretadas en base a una supuesta configuración a la "apología e instigación al crimen», entre otros, por la supuesta inducción al consumo de drogas a través del ejercicio de la libertad de expresión ${ }^{26}$.

Como no podía ser de otra manera, la respuesta de la Relatoría Especial para la Libertad de Expresión fue contundente, recordando nuevamente que salvo en los casos de expresiones en «favor de la guerra o la apología del odio nacional, racial o religioso que constituyan incitaciones a la violencia o cualquier otra acción ilegal similar contra cualquier grupo de persona o grupo de

${ }^{24}$ A través de un amplio informe, la Relatoría Especial para la Libertad de Expresión de la Comisión Interamericana de Derechos Humanos, expone los límites a la restricción de la libertad de expresión que establecen tanto la Comisión como la Corte Interamericana, apuntando que estas Instituciones exigen entre otros, que las restricciones se apliquen a «todos los elementos constitutivos de la libertad de expresión, en sus diversas manifestaciones», quedando ahí implicados los medios de comunicación y las propias Instituciones. Vid. Comisión Interamericana de Derechos Humanos, op. cit., ep. 59, p. 136.

${ }^{25} \mathrm{La}$ «necesidad»y, por ende, la legalidad de las restricciones a la libertad de expresión fundadas en el artículo 13.2 de la Convención americana, dependerá de que estén orientadas a satisfacer un interés público imperativo, que prepondere claramente sobre la necesidad social del pleno goce del derecho que el artículo 13 garantiza. Entre varias opciones para alcanzar ese objetivo, debe escogerse aquélla que restrinja en menor escala el derecho protegido. Lo anterior se aplica a las leyes, así como a las decisiones y actos administrativos y de cualquier otra índole, es decir, a toda manifestación del poder estatal.

Vid. Corte Interamericana de Derechos Humanos, Caso López Álvarez vs. Honduras, Sentencia de 1 de febrero de 2006, Serie C, No. 141, Ep. 165, p, 149- 150.

${ }^{26}$ Vid. Article 19, «BRAZIL: Marijuana March prohibited, demonstrators detained in clear violation of freedom of expression», (2008). http://www.article19.org. 
personas ${ }^{27}$, la libertad de expresión protege no únicamente la difusión de ideas e informaciones recibidas favorablemente, inofensivas o indiferentes; además quedarán amparadas igualmente, aquellas que ofenden, inquietan, resultan ingratas o perturban al Estado o sector de la población, tal y como lo exigen los principios del pluralismo y tolerancia de cualquier democracia.

Es por ello, por lo que sentenció que «las marchas ciudadanas pacíficas en el espacio público son manifestaciones protegidas por el derecho a la libertad de expresión ${ }^{28}$, refutando así cualquier injerencia del Estado que trate de adoptar cualquier tipo de decisión infundada o arbitraria que dé lugar a un efecto general de silenciamiento - «chilling effect»- fuera de los supuestos expuestos $^{29}$.

\section{CASOS OTEGUI Y FÉRET. EL DISCURSO DEL ODIO SEGÚN LOS TRIBUNALES EUROPEOS}

«El derecho a la libertad de expresión da cobertura no sólo a las ideas e informaciones aceptadas favorablemente o consideradas como inofensivas o indiferentes, sino también a aquellas que molestan, chocan o inquietan, pues así lo requieren el pluralismo, la tolerancia y el espíritu de apertura sin los cuales no hay sociedad democrática». De forma análoga a los pronunciamientos de la Corte Interamericana el TEDH, ha tenido ocasión de pronunciarse en relación al artículo 10.2 del $\mathrm{CEDH}^{30}$.

En relación a esta interpretación positivista de la libertad de expresión, el propio Tribunal Constitucional español (TC) ha tenido ocasión de pronunciarse, admitiendo que ciertamente «el ámbito constitucionalmente protegido

27 Vid. Comisión Interamericana de Derechos Humanos, op. cit., Ep. 50, p. 40.

28 Vid. Ibídem, Ep. 50, p, 40.

29 Basta acá con señalar que algunos de los argumentos que soportan esta tesis se refieren, fundamentalmente, a la importancia de evitar la creación de marcos jurídicos que permitan al Estado adoptar decisiones arbitrarias o desproporcionadas que tengan un efecto general de silenciamiento («chilling effect»). Ibídem, Ep. 57, p. 207.

30 La libertad de expresión no ampara únicamente aquellas informaciones o ideas acogidas con favor o consideradas inofensivas o indiferentes, sino también para aquellas que contrarían, chocan o inquietan al Estado o a una parte cualquiera de la población. Vid. Sentencia del Tribunal Europeo de Derechos Humanos (STEDH) de 23 de septiembre de 1988 (Lediheux), STEDH de 23 de abril de 1992 (Castells), STEDH de 24 de febrero de 1997 (Haes y Gijsels), de 8 de julio de 1999 (Sürek Baskaya y Okçuoglu) y 29 de septiembre de 1999 (Oztürk). En esta misma línea se ha venido manifestando el Tribunal Constitucional español, al reconocer a través de su jurisprudencia, que «la libre difusión de ideas y opiniones es que, según hemos reiterado, la libertad de expresión comprende la libertad de crítica, aún cuando la misma sea desabrida y pueda molestar, inquietar o disgustar a quien se dirige, pues así lo requieren el pluralismo, la tolerancia y el espíritu de apertura, sin los cuales no existe «sociedad democrática»». Vid. entre otras, STC 174/2006, de 5 de junio, FJ 4 y STC 235/2007, de 7 de noviembre, FJ 4. 
de la libertad de expresión no puede verse restringido por el hecho de que se utilice para la difusión de ideas u opiniones contrarias a la esencia misma de la Constitución» ${ }^{31}$. Advierte el TC que el legítimo ejercicio de la libertad de expresión, no implica que pueda llegar a ser considerado como un «derecho absoluto ${ }^{32}$, a través del cual, se puedan difundir frases y expresiones ultrajantes u ofensivas no relacionadas con el propósito, tal y como ocurre, con los discursos racistas o xenófobos. Acertadamente el TC aparta de la protección que brinda el artículo 20.1 CE a este tipo de discursos, que menosprecian y estigmatizan a grupos de personas por sus especiales características, argumentando, que proteger este tipo de actuaciones amparándose en la cobertura del artículo 20.1 de la Constitución implicaría permitir, la «violación de unos de los valores superiores del ordenamiento jurídico, como es la igualdad $»^{33}$, y la dignidad de las personas. De tal forma que aquellas manifestaciones racistas, humillantes, vilipendiadoras o que incitan directamente a actitudes constitucionalmente inaceptables, quedarían descubiertas del amparo del artículo 20.1 CE. Advierte su reconocida jurisprudencia que «el odio y el desprecio a todo un pueblo o a una etnia son incompatibles con el respeto a la dignidad humana» ${ }^{34}$.

\subsection{Otegui Mondragón vs. España: controversia, «chilling effect» y obstinación}

En relación a la consideración o no de la libertad de expresión como un derecho absoluto y cuándo y cómo delimitar su cobertura, hemos tenido ocasión de asistir entre otras, a la STEDH del 15 de marzo de 2011, caso Otegui vs. España.

El conocido caso Otegui, surgió como consecuencia de una querella presentada por la Fiscalía en relación a unas declaraciones públicas realizadas por el portavoz del grupo parlamentario Sozialista Abertzaleak en contra del

31 Vid. Sentencia del Tribunal Constitucional (STC) 235/2007, de 7 de noviembre de 2007, FJ 4.

32 «Todo lo dicho no implica que la libre transmisión de ideas, en sus diferentes manifestaciones, sea un derecho absoluto. De manera genérica, se sitúa fuera del ámbito de protección de dicho derecho la difusión de las frases y expresiones ultrajantes u ofensivas, sin relación con las ideas u opiniones que se quieran exponer, y por tanto, innecesarias a este propósito» $[\ldots]$ «En concreto, por lo que hace a las manifestaciones, expresiones o campañas de carácter racista o xenófobo, hemos concluido que el artículo 20.1 CE no garantiza "el derecho a expresar y difundir un determinado entendimiento de la historia $\mathrm{o}$ concepción del mundo con el deliberado ánimo de menospreciar y discriminar, al tiempo de formularlo, a personas o grupos por razón de cualquier condición o circunstancia personal, étnica o social...”» Vid. Ibídem, FJ 5.

33 Vid. Ibídem, FJ 5.

34 Vid. STC 214/1991, de 11 de noviembre, FJ 8. 
Jefe de Estado ${ }^{35}$. De la lectura de dichas declaraciones y del fallo en primera instancia del Tribunal Superior de Justicia del País Vasco (STSJPV), se desprendía, inclusive a través del único voto concordante, que tales declaraciones fueron realizadas en el «ejercicio del derecho a la libertad de expresión, al no exceder de las limitaciones constitucionales con que ha de ser ejercido este derecho fundamental» ${ }^{36}$.

Como es sabido, dicha sentencia fue anulada por el Tribunal Supremo, quien consideró que a través de aquellas declaraciones, «el ejercicio del derecho fundamental de la libertad de expresión resulta, con toda evidencia, contrario al principio de proporcionalidad y, por lo tanto, absolutamente in-

${ }^{35}$ En concreto, el Sr. Otegui como portavoz del grupo parlamentario al que representaba, realizó una serie de declaraciones en relación a una operación policial contra el periódico Egunkaria. En las mismas, sostenía que el Rey (Jefe del Estado Español y jefe de las Fuerzas Armadas -incluyendo en estas a la Guardia Civil-), era el jefe de los que habían torturado a las personas detenidas en la operación llevada a cabo contra el mencionado periódico. Taxativamente las palabras de Otegui, en relación a una inauguración conjunta con el presidente del Gobierno Vasco: «¿Cómo es posible que se fotografíen hoy en Bilbao con el rey de España, cuando el rey de España es el jefe supremo del ejército español, es decir el responsable de los torturadores y el que protege la tortura y que impone su régimen monárquico a nuestro pueblo a través de la tortura y la violencia?». Vid. STEDH de 15 de marzo de 2011, caso Otegui Mondragón vs. España (Denuncia no 2034/07).

${ }^{36}$ En opinión del magistrado disidente, Bolado Zárraga, ninguna de las expresiones proferidas se refieren a aspectos personales de la vida personal del monarca, resultando un fiel reflejo de la postura política del portavoz del grupo parlamentario, «contraria a la forma de Estado de la Monarquía Parlamentaria establecida en la Constitución y proclive a la independencia del País Vasco». Enlazando así al Jefe Supremo de las Fuerzas Armadas y mando de la Guardia Civil -al ser este un cuerpo de carácter militar- como «Jefe de los que han torturado a Víctor Manuel, Alexander y a todos los detenidos», hecho reiterado a través de denuncias que han sido constantemente repetidas «por miembros del grupo político donde se integra el acusado y en alguna ocasión han dado lugar a la incoación de proceso penal relativo a los hechos denunciados»»». En esta línea apuntan entre otros Amnistía Internacional quien exhorta a la eliminación de «espacios de impunidad para los graves abusos contra los derechos humanos cometidos por ETA y deben también investigarse los cometidos por las Fuerzas y Cuerpos de Seguridad del Estado español». Vid. Amnistía Internacional, «Una agenda de derechos humanos para la X legislatura en España», Sección española de amnistía internacional, Madrid, 2012, p. 29. Es por ello, por lo que «partiendo por tanto de esa enemistad, constitucionalmente lícita, a la institución monárquica y al Estado en el que se integra el País Vasco, se advierte claramente que las manifestaciones que se enjuician carecen de otro sentido, respecto de S.M. el Rey, que no sea la de su consideración como Jefe del Estado, a quien el acusado atribuye autoridad directa sobre todos los órganos de la administración estatal; y siendo este el sentido que indudablemente corresponde a tales manifestaciones, las censuras que ellas puedan merecer no deben alcanzar una consideración jurídica que prevalezca sobre el respeto al derecho constitucional de la libertad de expresión». Vid. Sentencia del Tribunal Superior de Justicia del País Vasco (Bilbao), Sala de lo Civil Penal, 18 de Marzo de 2005, Número de Recurso: 7/2003, Voto Concordante, Ep. Séptimo. 
necesario, superándose con mucho lo que pudieran considerarse críticas hirientes, molestas o desabrida ${ }^{37}$, considerando que aquellas fueron unas declaraciones ignominiosas que pretendían herir o molestar la dignidad del Jefe del Estado.

En voto disidente -que compartimos-el magistrado Ibañez apuntó que el uso de la libertad de expresión se «amplía sensiblemente cuando versa sobre instituciones, dado que éstas no gozan de ese atributo exclusivo de la persona, que es el honor. Y, por tanto, su presencia en la esfera pública tiene lugar en un régimen de protección de intensidad menor, que la reconocida a los particulares $\gg{ }^{38}$.

Ciertamente en esta línea apuntaba, entre otros, el Relator Especial de las Naciones Unidas para la Libertad de Opinión y Expresión, que en declaración conjunta, advertía que cualquier tipo de restricciones a la libertad de expresión debe limitarse a la protección de intereses sociales y derechos individuales imperativos, $\mathrm{y}$ «no debe usarse nunca para proteger instituciones particulares ni nociones, conceptos o creencias abstractas $\rangle^{39}$.

Discreparon de esa última tesis, parte de la doctrina, así Serrano Maíllo proponía desplazar la figura del Rey de la categoría de político, al no participar aquél en la disputa política. Repuntando que para el TEDH, la «libertad de expresión es especialmente valiosa en manos de esos sujetos, dado que en definitiva han sido elegido por el pueblo» ${ }^{40}$.

Con tales premisas, entenderíamos que la libertad de expresión resultaría más amplia si proviene de la clase política, resultando de esta forma aún más fuerte la voz del parlamentario Abertzaleak, dado que guste o no, entre las dos personalidades, el señor Otegui fue el único elegido por sufragio universal. Soto García destaca dos elementos de la jurisprudencia del TEDH en relación a este caso, que el artículo 10. 2 del CEDH apenas deja lugar a res-

37 Vid. Sentencia del Tribunal Supremo 1284/2005 de 31 de octubre de 2005, FD, Tercero.

38 Vid. Ibídem, Voto Disidente.

39 En líneas semejantes se ha pronunciado también la Asamblea General de la Organización de Estados Americanos, mediante Resolución 2434 (XXXVIII-0/08) sobre Derecho a la libertad de pensamiento y expresión y la importancia de los medios de comunicación. Donde la Relatoría Especial de la CIDH invita a los Estados a derogar las leyes que tipifiquen delitos de desacato, difamación injuria y calumnia, supeditando el control de estas conductas al derecho civil. Vid. Relator Especial de las Naciones Unidas para la Libertad de Opinión y Expresión; Representante de la Organización para la Seguridad y Cooperación en Europa,..., «Declaración conjunta sobre difamación de religiones sobre legislación antiterrorista y anti-extremista», Campaña Global para la libertad de expresión, Atenas, (2008).

${ }^{40}$ Vid. SerRano Maíllo, I., «El derecho a la libertad de expresión en la jurisprudencia del tribunal europeo de derechos humanos: dos casos españoles», Teoría y Realidad Constitucional, UNED, Vol. 28, 2011, pp. 591 y ss. 
tricciones a la libertad de expresión en el ámbito del discurso político y el especial valor que esa libertad tiene, para un «electo por el pueblo, que representa a sus electores $\rangle^{41}$.

Al mismo tiempo, aquellas declaraciones no fueron ajenas a la realidad política del momento, pese a que Serrano Maíllo sostenga que el TEDH diera «muestras de su desconocimiento de la situación que vive el País Vasco» ${ }^{42}$. A este respecto, el propio fallo del TSJPV hizo expresa mención al problema del terrorismo y a las reiteradas vulneraciones de los derechos humanos a través de torturas. En esta línea se postula, entre otros, Landa Gorostiza, quien sostiene que en el País Vasco además de la actividad terrorista de ETA, existe un «pasado pre-constitucional y, en parte, post-constitucional, en el que los aparatos del Estado -o grupos que contaban con su connivencia e impunidad- han protagonizado violaciones graves y sistemáticas de los derechos humanos que, hasta ahora al menos, han pasado por un modelo de transición de olvido y punto final» ${ }^{43}$.

No debemos pasar por inadvertido que fuera el propio TEDH, quien condenara a España por vulneración del artículo 3 del CEDH, en caso de malos tratos a un detenido de la organización terrorista $\mathrm{ETA}^{44}$, y que, el Relator

${ }^{41}$ Soto García, M., «TEDH - Sentencia de 15.03.2011, Otegui Mondragón c. España, 2034/07 - Artículo 10 del CEDH - Libertad de Expresión - Límites - Delito de Injurias contra el Jefe del Estado - Exhortación a la Violencia y Discurso de Odio», Revista de Derecho Comunitario Europeo, Vol. 42, Madrid, 2012, pp. 583-84.

${ }_{42}$ Recordemos que el TEDH, ya ha tenido ocasión de pronunciarse en caso similar, condenando a España por vulneración del artículo 10 del CEDH, al haber condenado al senador del grupo Herri Batasuna -Castells, por injuriar gravemente al gobierno a través de unas declaraciones realizadas en un semanario. De la lectura de las mismas, el TEDH no apreció ningún tipo de incitación a la violencia ni apología de la misma. Desprendiéndose más bien, sentimientos de impotencia ante -según su exposición- la impunidad de unas acciones de las que solo pueden estar «el Gobierno, el partido del gobierno y sus efectivos». Vid. STEDH de 23 de abril de 1992, Castells vs. España.

${ }^{43}$ En alusión a los intentos de clasificación por parte del Estado español, de la actividad terrorista del grupo ETA, como crímenes contra la humanidad, al margen de la responsabilidad del Estado por las múltiples violaciones de derechos humanos -no registradas- de las cuales ya ha tenido tácitamente conocimiento el TEDH, entre otros, a través de STEDH de 23 de abril de 1992, Castells vs. España. Acertadamente, supone -el autory siguiendo entre otros a GIL GIL, que «el discurso de los derechos humanos sea manipulado por el Estado para zafarse de sus responsabilidades y obligaciones internacionales», supone un ejercicio de «blanqueo de sepulturas inaceptable». Vid. LANDA GorostizA, J.M., «La sombra en los crímenes contra la humanidad en la política anti-terrorista española: reflexiones críticas», Revista Electrónica de Ciencia Penal y Criminología, (2010), p, 10: 29 y ss.

${ }^{44}$ Vid. Caso San Arguiiro Isasa vs. España, recurso núm. 2507/07, Sentencia del TEDH de 28 de septiembre de 2010,. 
especial de la ONU, Van Boven, concluyera precisando que el sistema penal español «permite la ocurrencia de tortura o malos tratos» ${ }^{45}$.

Entre sus conclusiones, Serrano Maíllo sentenció que las «declaraciones de Otegui debieron ser consideradas por el TEDH como un ejemplo claro del denominado discurso del odio» ${ }^{46}$. Sin embargo, al no quedar constatado que a través de las mismas se desencadenara una incitación a la violencia ${ }^{47}$ contra cualquier persona o grupo de personas, o bien, a través del odio nacional, racial o religioso, no existe razón para que las mismas puedan ser categorizadas en ningún caso como un tipo de «hate speech $»^{48}$, resultando in fine, un mero ataque contra las Instituciones al que cualquier intento de silenciamiento -chilling effect- debe de ser considerado contrario al artículo 10 del CEDH.

En líneas semejantes se ha venido manifestando el TC, cuando destaca que es «precisamente cuando se presentan ideas que sorprenden, que chocan y que contestan el orden establecido, es cuando la libertad de expresión es más preciada $»^{49}$.

Como bien apuntó el juez De Meyer, «en caso de injurias, calumnias y difamación, no conviene que las instituciones estén más protegidas que las personas

${ }^{45}$ A través de un amplio informe sobre España, el Relator Especial sobre la cuestión de la tortura Theo van Boven, analiza entre otros el caso de las detenciones llevadas a cabo consecuencia del cierre del periódico Egungaria -motivo de las declaraciones analizadas a priori-. Para Van Boven, en sintonía con las opiniones expresadas por los tribunales y órganos regionales de derechos humanos, inter alia, «la detención incomunicada prolongada puede facilitar la práctica de la tortura y equivale en sí a una forma de trato cruel, inhumano o degradante» Vid. VAN Boven, T., «Los Derechos Civiles y Políticos, en Particular las Cuestiones Relacionadas con la Tortura y la Detención». Informe del Relator Especial sobre la cuestión de la tortura, $60^{\circ}$ periodo de sesiones, E/CN. 4/2004/56/ Add. 2, 2004, Ep.30 y ss.

46 Vid. Serrano Maíllo, op. cit., p. 593.

47 «El elemento esencial a tomar en consideración ha de ser la inexistencia de exhortación a la violencia o de un discurso de odio, que la Corte no aprecia en el caso, a pesar de que se bosquejara una imagen negativa del Rey como institución y ello diera al relato una connotación hostil». Soto García. op. cit., p. 586.

${ }^{48}$ En comentario al presente fallo del TEDH se sostiene que si bien el lenguaje del parlamentario fue una provocación, hubo unas ciertas «dosis de exageración, pues en todo caso no se exhortó a la violencia o al discurso del odio». Vid. AA.VV., «Libertad de Expresión (art. $10 \mathrm{CEDH}) »$, Revista de Justicia Administrativa. Derechos Fundamentales y Libertades Públicas, núm. 52, (2011), p.98.

49 Así el Tribunal Constitucional ha tenido ocasión de pronunciarse «más allá del riesgo, indeseable en el Estado de democrático, de hacer del Derecho penal un factor de disuasión del ejercicio de la libertad de expresión [...] a las normas penales les está vedado invadir el contenido constitucionalmente garantizado de los derechos fundamentales». «Nuestro ordenamiento constitucional no permite la tipificación como delito la mera transmisión de ideas, ni siquiera en los casos en que se trate de ideas execrables por resultar contrarias a la dignidad humana...»Vid. STC 235/2007, de 7 de noviembre de 2007, FJ, 6. 
y que el Gobierno lo esté más que la oposición» ${ }^{50}$. Se comprende aquí, que aquel discurso en litigio no se exhortó al uso de la violencia, no correspondiéndose por tanto con un discurso de odio, al no cumplir con el elemento esencial-según la propia jurisprudencia del TEDH-de inculcar un «odio profundo e irracional $»^{51}$.

\subsection{Estado español y la jurisprudencia de Estrasburgo}

Pese a la mencionada condena firme a España por violación del artículo 10 del CEDH -caso Otegui- y de los mencionados convenios internacionales en materia de libertad de expresión y discurso de odio; la justicia española persevera en el blindaje de la figura del Jefe de Estado. Nuevamente el pasado 14 de marzo de 2013 -en contra de la mencionada jurisprudencia del TEDH- la Audiencia Nacional (AN), condenaba por delito de calumnias e injurias graves contra la Corona, al ex-coronel del ejército Martínez Inglés, por la publicación de un artículo en un diario de difusión limitada en el que aparentemente se menospreciaba la figura del Jefe del Estado, sin incitar al odio o la violencia ${ }^{52}$.

Es precisamente en aquellos discursos litigiosos que no muestran evidencias de rebasar los límites de la libertad de expresión donde la $\mathrm{CADH}$, ha delimitado con mayor certeza los márgenes, respecto al CEDH. Posiblemente por ello, en el espacio europeo se están encontrando sentencias tan contradictorias, como la tan criticada por un sector de la doctrina, STC235/2007, de 7 de noviembre, por la que se despenaliza la negación del holocausto, al considerar en principio inane, «la mera negación del delito» ${ }^{53}$.

${ }^{50}$ Vid. Caso Castells vs. España, recurso núm. 11798/85, Sentencia del TEDH de 23 de abril de 1992. Voto Concordante.

${ }^{51}$ El TEDH, recuerda que en su propia jurisprudencia, para que se den los presupuestos necesarios en los que se pueda limitar el ejercicio de la libertad de expresión, «the Court reiterates that the mere fact that «information» or «ideas» offend, shock or disturb does not suffice to justify that interference [...] What is in issue in the instant case, however, is hate speech and the glorification of violence». Vid. Caso Sürek vs. Turquía, (no 1) [GC], rec. núm. 26682/95, § 62.

${ }_{52}$ Eludiendo comentada jurisprudencia del TEDH, al respecto de la protección del ejercicio a la libertad de expresión en lo referente, a proteger la imagen de las personalidades políticas, el Magistrado Vázquez Honrubia, condenó al ex-coronel, por divulgar en un medio digital de difusión limitada (Canarias-digital), afirmaciones como que Franco fue el tercer dictador más sanguinario de Europa, o que el actual Jefe de Estado, traicionó a la nación española al pactar en 1975 con el Departamento de Estado norteamericano «la entrega vergonzante a Marruecos de la totalidad de la antigua provincia española del Sáhara Occidental», entre otras que sin ser generadoras de odio, no podemos compartir. Lo más sorprendente, es que el propio Magistrado, eludió la jurisprudencia del caso Otegui, cuando en el FJ. 4, refiere la STS de 31 de octubre de 2005 (caso Otegui). Vid. Sentencia de la Audiencia Nacional núm. 16/2013, de 14 de marzo de 2013, FJ. 4.

53 En otros países de nuestro entorno - principalmente Alemania, artículo 130 StGBla mera negación o minimización pública de los hechos cometidos por el régimen Nacio- 
Entre otros, Landa Gorostiza, acertadamente apunta que a través de dicha sentencia, el TC recoge los «criterios interpretativos del discurso de odio», priorizando el área de la libertad de expresión y desplazando así la intervención penal ${ }^{54}$. Todo ello, tal y como indica el propio TC, frente a otras conductas de juicio positivo «que comportan adhesión valorativa al hecho criminal» ${ }^{55}$.

\subsection{Féret vs. Bélgica: TEDH y «hate speech» en politica}

La referida adhesión valorativa que proponía el TC al respecto de la mera negación de un delito, en cierto sentido, se da entre otros, en el conocido caso Féret vs. Bélgica.

Nótese que en el asunto Féret, al contrario que el caso Otegui en el que el las declaraciones - no se trató de un discurso programado- se dirigían contra una figura pública, en este, el discurso - más agresivo, contundente y programado- se dirigía contra determinados colectivos, inmigrantes y musulmanes principalmente. Proponía el líder belga, la expulsión y segregación social de los inmigrantes no comunitarios y de los musulmanes; consolidando así en sus discursos, claras evidencias xenófobas e islamófobas que resultaban contrarias, de iure, a lo establecido entre otros, en el artículo 4 del CIEDR.

Parte de la doctrina como Alcácer Guirao -con quien no coincidimos en este planteamiento- consideran que la sentencia del asunto Féret fue «rechazable desde los propios parámetros manejados habitualmente por el TEDH en materia de libertad de expresión, pues constituye una restricción excesiva e injustificada del derecho fundamental en el ámbito donde su protección en un Estado constitucional debería ser más intensa» ${ }^{56}$. A este respecto coincidimos con Rosenfeld, quien considera que los sentimientos contra los inmigrantes pueden ser producto de temores de ver peligrar la propia seguridad económica y los valores culturales. Esos temores, deberían ser libremente discutidos y debe actuarse con cautela cuando se en-

nalsocialista, continúa siendo tipificada. Sin embargo, nos queda la duda de si bajo tal precepto, sería punible la negación pública de los crímenes cometidos por Stalin, Pol Pot, Mussolini, Franco o Nixón, entre otros. Consideramos que la inserción de tal precepto en el Código penal germano, supone un acto más de lavado de imágenes pasadas.

54 Vid. LANDA Gorostiza, J.M., «Incitación al odio: evolución jurisprudencial (1995-2011) del art. 510 CP y propuesta de lege lata», Revista de Derecho Penal y Criminología, 3. época, Vol. 7, 2012, p, 329.

55 STC 235/2007, de 7 de noviembre de 2007, FJ 8.

56 Vid. AlCÁcer Guirao, R., «Discurso del odio y discurso político. En defensa de la libertad de los intolerantes», Revista Electrónica de Ciencia Penal y Criminología, Vol. 14-02, 2012, pp. 30-62. p. 02: 8 . 
frenta a lo que parece ser un «discurso de odio en sustancia, pero no es discurso de odio en forma» ${ }^{57}$.

Sin embargo, aquél ataque dialéctico y mediático a través de la propaganda, determinó que la condición de parlamentario no le podía eximir de responsabilidad, por lo que el Sr. Féret fue condenado según la Ley belga de 30 de julio de 1981, sobre la represión de determinados actos basados en el racismo. Ley por cierto, que a juicio del Comité para la Eliminación de la Discriminación Racial, no parecía atender todos los requisitos del artículo 4 del CIEDR ${ }^{58}$.

A través del caso Féret, el TEDH hizo un llamamiento recordando que es del todo crucial, «que los políticos en sus discursos públicos, eviten difundir declaraciones que tiendan a alimentar la intolerancia $\rangle^{59}$.

Probablemente el mayor obstáculo al que se deben enfrentar los tribunales a la hora de dirimir en este tipo de casos, es determinar cuando unas declaraciones alientan o no la intolerancia; o si por el contrario, como sostiene Alcácer Guirao, pertenecen a un evidente animus iocandi que no corresponde con el estilo de «una arenga que persiga enervar los ánimos» ${ }^{60}$. A este respecto Sottiaux confirma que en el caso Féret el tipo de discurso es apropiado calificarlo como incitador al odio racial y la discriminación de forma intencionada ${ }^{61}$. Para el TEDH, parece quedar claro que «el odio no requiere un determinado acto de violencia o acto criminal», difamaciones contra sec-

${ }^{57}$ Rosenfeld, M., «El discurso del odio en la jurisprudencia constitucional: análisis comparativo», Pensamiento Constitucional, Año XI, Núm. 1, p. 194.

${ }_{58}$ Según las observaciones del Comité para la Eliminación de la Discriminación Racial en Bélgica, la Ley de 30 de julio de 1981 sobre la represión de determinados actos basados en el racismo, si bien representaba un adelanto en la campaña de lucha contra la discriminación racial en Bélgica, el alcance de la Ley continua siendo limitado. Requiere el Comité, a su vez, información sustantiva adicional sobre las denuncias presentadas ante los tribunales en relación con el cumplimiento de la Ley, y sobre la existencia de grupos que promuevan la discriminación racial. Vid. Office for the High Comissioner for Human Rights, «Observaciones finales del Comité para la Eliminación de la Discriminación Racial», (1992), A/47/18, par. 44-68.

59 En esta línea se ha venido manifestando entre otros muchos, la Comisión Europea Contra el Racismo y la Intolerancia (ECRI), que recomienda encarecidamente a los partidos políticos, de resistir la tentación de presentar imágenes negativas respecto a personas extra comunitarias y de grupos minoritarios. «Los partidos políticos deben adoptar posiciones firmes contra cualquier forma de racismo, discriminación y xenofobia en política». Entre otros, Vid. Commissione Europea Contro el Razismo e 1'Intoleranza, «Terzo Rapporo sull Italia», Strasburgo, (2006), p, 28.

${ }^{60}$ Vid. Alcácer GuiraO, R., op. cit, p. 02: 26.

${ }^{61}$ Siguiendo la jurisprudencia del caso Keedstra, este autor asevera que «incitement is to mean active support or instigation, the intention requirement is to imply a subjective desire to stir up hatred, and hatred is to connote emotion of an intense and extreme nature that is clearly associated with vilification and detestation». Vid. SotTiauX, S., «"Bad Tendencies' in the ECtHR's 'Hate Speech' Jurisprudence», Europa Constitutional Law Review, (2011), p. 54. 
tores de la población, grupos específicos o la incitación a la discriminación, es suficiente para que las autoridades enfaticen la lucha contra el discurso racista y la libertad de expresión irresponsable ${ }^{62}$.

\section{CONCLUSIONES}

Con lo hasta aquí expuesto, podemos sostener que cualquier tipo de suceso motivado por odio, tiene un perfil de tipo emocional que será tan diverso como dispares sean, las ideologías, apreciaciones e interpretaciones. Tal y como describe Aniyar, los delitos de odio, son «crímenes motivados por las diferencias» ${ }^{63}$.

Pero, ¿hasta dónde se pueden permitir y limitar esas diferencias? A las dificultades procesales a la hora de imputar cualquier tipo de delito; cuando estos son causa de un móvil odioso, se adicciona la delimitación de los márgenes entre el respeto a la libertad de expresión y la prohibición penal de determinados discursos hirientes característicos de las democracias militantes. Acertadamente Alcácer Guirado apunta que exceptuando aquellos discursos que supongan una provocación directa a la violencia, restringir la libertad de expresión sin darse aquella inminente provocación, únicamente podría aceptarse «en sociedades en situación estructural de crisis, en las que las desigualdades existentes de facto entre grupos sociales sean de tal grado que impidan a algunos acceder en condiciones de igualdad al ejercicio de la libertad de expresión pública» ${ }^{64}$. Sin embargo, esta tesis nos evoca la necesidad de identificar qué tipo de sociedad puede llegar a ser considerada estable, es decir, ecuánime.

62 «La Cour estime que l'incitation à la haine ne requiert pas nécessairement l'appel à tel ou tel acte de violence ou à un autre acte délictueux. Les atteintes aux personnes commises en injuriant, en ridiculisant ou en diffamant certaines parties de la population et des groupes spécifiques de celle-ci ou l'incitation à la discrimination, comme cela a été le cas en l'espèce, suffisent pour que les autorités privilégient la lutte contre le discours raciste face à une liberté d'expression irresponsable et portant atteinte à la dignité, voire à la sécurité de ces parties ou de ces groupes de la population. Les discours politiques qui incitent à la haine fondée sur les préjugés religieux, ethniques ou culturels représentent un danger pour la paix sociale et la stabilité politique dans les Etats démocratiques ». Vid. STEDH de 16 de julio de 2009, Féret vs. Bélgica, No. 15615/07, \& 73.

${ }^{63}$ Vid. Aniyar de Castro, L., op. cit., p. 15.

${ }^{64}$ Advierte este autor, que en este tipo de sociedades, cualquier discurso de odio caería en un campo de cultivo abonado previamente para la discriminación, generando entonces un menoscabo de las condiciones de seguridad del colectivo discriminado. Reconoce que en una sociedad inestable, el ejercicio de la libertad de expresión de las minorías no sería instrumento suficiente para hacer frente al discurso del odio y que solo en una «sociedad estable», sin desequilibrios ni desigualdades entre colectivos, dispondrá de los mecanismos necesarios para hacer frente al discurso del odio sin ser necesario acudir a los instrumentos finales de la pena. Vid. AlCÁCER GUIRAO, op. cit., p. 02: 30. 
Sin lugar a dudas, en una sociedad ideal, en la que todas las voces dispongan del mismo derecho legítimo y universal de pronunciarse al mismo nivel, resultaría sencillo neutralizar cualquier tipo de discurso de odio proveniente de alguna corriente minoritaria.

Trasponiendo aquella sociedad ideal, a cualquier sociedad convencional moderna en la que obviamente, pese a existir un derecho a la libertad de expresión reconocido, ciertamente no todas las voces suenan igual de fuertes ni tienen la misma difusión, la tesis de Alcácer, difícilmente sería válida. En esa línea apunta Serrano, acerca de unas declaraciones del político José Bono.

En caso similar al de las declaraciones que originaron el caso Otegui vs. España; el parlamentario del Grupo Socialista José Bono, declaraba públicamente que Arnaldo Otegui era «un secuestrador» ${ }^{65}$, en relación a dos asuntos en los que resultaron afectados dos políticos y que pese a conocer la inocencia del político vasco -al haber sido absuelto- y la gravedad de las acusaciones, Bono, se permitió continuar acusándole sirviéndose de la injusta cobertura mediática.

A través de un riguroso análisis, este autor muestra ejemplos en los que a través de los medios se trata de justificar la «guerra como método de resolución frente al diálogo», haciendo mención entre otros, al documental «la revolución de la libertad» de la fundación FAES ${ }^{66}$.

Lo cierto es que el calado y la influencia con la que los medios de comunicación inciden en la sociedad no tienen parangón y ha venido utilizándose en contra del derecho internacional de los derechos humanos por los poderes públicos. Entre otros, la denominada por Miralles, «vergonzante guerra desatada por la OTAN y el visto bueno de Naciones Unidas para derrocar al dictador en Libia» ${ }^{67}$; los efectos devastadores de la guerra de los Balcanes; los de las invasiones de Afganistán e Irak, en los que -en contra de las reso-

${ }^{65}$ Las diferencias entre las declaraciones «ignominiosas»-tal y como las denominó el TC, del parlamentario Otegui contra el Jefe del Estado al llamarle «jefe de los torturadores», y las declaraciones del socialista Bono, al llamar a Otegui «secuestrador», nos resultan sino similares, tal vez, aún más directas las segundas al imputar directamente al parlamentario vasco y atreverse a «juzgar por lo que ha hecho». Vid. ETA.- Europapress. es, «Bono recuerda que el «angelito» Otegi secuestró a Javier...» 27/10/2011. «Pero Otegui fue juzgado por ambos delitos y absuelto y los que son absueltos de un juicio de secuestro no son secuestradores. Bono se podía permitir llamar secuestrador a alguien que había sido absuelto de esa acusación porque la satanización mediática ya se había previamente conseguido». Vid. Serrano, P., Medios Violentos. Palabras e imágenes para el odio y la guerra, Ed. El Viejo Topo, Barcelona, 2008, p. 55.

${ }_{66}$ Serrano, op.cit., p. 68 y ss.

${ }^{67}$ Miralles Sangro, P.P., «Democracia, derechos humanos y constitución exigen el cierre inmediato de los centros de internamiento de extranjeros (CIES)», Revista de Derecho UNED, Vol. 10, 2012, p. 736. 
luciones de la ONU-a través de una vilipendiadora manipulación mediática, se trató de convencer a la comunidad internacional de la necesidad de emprender la devastadora «War on Terror». En todas y cada una de ellas, el discurso del odio emitido a través de los medios de comunicación fue el instrumento de justificación e incitación a la guerra ${ }^{68}$.

Jiménez Moliner detecta siete tipos de manifestaciones de odio en el conflicto de los Balcanes: la negación de la existencia de minorías o incluso de una determinada etnia; la imagen negativa de los inmigrantes, minorías religiosas y étnicas y los extranjeros; ataques contra representantes o líderes de las minorías; ataques contra ONGs, periodistas o intelectuales; ataques contra Occidente; «hate speech» fundado en «no hechos» $\mathrm{y}$ «hate speech» provocador de violencia ${ }^{69}$. Identifica esta autora el discurso del odio «por la utilización de un vocabulario discriminatorio, cuidadosamente seleccionado, dirigido a legitimar la consideración negativa y despectiva de todos aquellos que no pertenecen al nosotros $\gg^{70}$.

Consideramos que el libre intercambio de ideas, incluidas las ofensivas, es «crucial para las fricciones saludables de un sistema plural» $»^{71}$, no criminalizando únicamente aquellas hirientes al Estado o sus Instituciones, como si de una democracia militante se tratara y obligando a cumplir los límites ya establecidos por las Convenciones internacionales a los propios órganos legislativos $^{72}$.

Por todo ello, una vez más sostenemos -en la línea de la Declaración Conjunta sobre Difamación de Religiones y sobre Legislación Anti-terrorista y Anti-extremista- que la mejor manera de afrontar la existencia de prejui-

${ }^{68}$ Entre otros, Michael Moore trata de documentar como el entonces presidente de los Estados Unidos de América, utilizó los medios de comunicación para promover sendos holocaustos -Afganistán e Irak-, bajo el pretexto de la seguridad internacional y con la única meta de asegurar inmensos beneficios petroleros para las compañías norteamericanas. Vid. Moore, M., Fahrenheit 9/11, documental, USA, (2004).

${ }^{69}$ En circunstancias no ajenas a la situación política actual española, en 1990, de un día para otro se dejó de emitir en legua albanesa en la televisión y radio kosovares, comenzando a emitir casi exclusivamente en lengua serbia, etiquetando como «terrorista, traidores y enemigos del estado a quienes antes abogaban por la independencia de Kosovo». Vid. JimÉnez Moliner, A., «Medios de comunicación y hate speech en las sociedades post-totalitarias: el paradigma de Kosovo», Cuadernos Cátedra Fabrique Furió, Vol. $50 / 51,2005$, p. 125 y ss.

70 Vid. Ibídem, p. 130.

71 Vid. Pokempner, D., «Libertad de expresión y guerra contra el terrorismo», Política Exterior, Núm. 127, (2009), p. 168.

72 En su cuarto informe sobre España, la ECRI detectó un partido político abiertamente xenófobo, la Plataforma por Cataluña a la vez de diversos brotes de discursos de odio en las filas del Partido Popular, contra inmigrantes rumanos y gitanos. Vid. Comisión Europea contra el Racismo y la Intolerancia (ECRI), "Cuarto Informe sobre España», (2011), Ep. 93. 
cios sociales, es a través de un diálogo abierto, que exponga el daño causado por tales prejuicios y combata los estereotipos negativos ${ }^{73}$. Diálogo, que hasta cierto punto, ha venido caracterizando a la sociedad española, respecto de otras sociedades que han sufrido los efectos devastadores del terrorismo ${ }^{74}$, pero que a día de hoy, es posible que pase a la historia ${ }^{75}$.

\section{BIBLIOGRAFÍA}

AA.VV., «A Policymaker's Guide to Hate Crimes», Ed. Bureau of Justice Assistance, Washington, 1997.

«Libertad de Expresión (art. 10 CEDH)», Revista de Justicia Administrativa, Derechos Fundamentales y Libertades Públicas, Vol. 52, 2011.

AlCÁCer Guirao, R., «Discurso del odio y discurso político. En defensa de la libertad de los intolerantes», Revista Electrónica de Ciencia Penal y Criminología, Vol. 14-02, 2012, pp. 30-62.

Aniyar de Castro, L., «Los Crímenes de Odio: Discurso Político y Delincuencia Violenta en Venezuela. El Respeto a las Diferencias y el Rol de la Criminología Crítica en Venezuela en los Inicios del Siglo XXI», Capitulo Criminológico, Vol. $36, \mathrm{n}^{\circ} 2,2008$, pp. 5-39.

Gimenez-Salinas i Colomer, E., Román Maestre, B., García Solé, M., «Sociedad Abierta y Delitos de Odio en la Era de la Globalización», Eguzkilore: Cuaderno del Instituto Vasco de Criminología, Universidad Ramón Lluch, Barcelona, Vol. 17, San Sebastián, 2003, pp. 121-132.

Goodey, J. \& AromaA, K., Hate Crimes. Papers from the 2006 and 2007 Stockholm Criminology Symposiums, Ed. Criminal Justice Press, Helsinki, 2007.

Jacobs, J.B. y Potter, K., Hate Crimes. Criminal Law and Identity Politics, Ed. Oxford University Press, New York, 1998.

${ }^{73}$ La asamblea parlamentaría del Consejo de Europa, propone: un mayor énfasis en la educación para la ciudadanía democrática; fortalecimiento del diálogo intercultural e interreligioso; aplicación de las políticas socioeconómicas dirigidas a contribuir a la erradicación del racismo, la xenofobia y la intolerancia en la sociedad. Vid. Asamblea Parlamentaria del Consejo de Europa, «Resolution 1754. Fight against extremism: achievements, deficiencies and failures», (2010).

74 «El tan temido aumento de los crímenes de odio contra marroquíes o musulmanes de cualquier nacionalidad no se ha materializado. Hasta donde sabemos, no se ha producido ningún caso claramente demostrado de violencia racista que pueda atribuirse directamente a los atentados del 11 de marzo» Vid. Human Rights Watch, «¿Sentando Ejemplo? Medidas anti-terroristas en España», New York, (2005).

${ }_{75}$ Apunta Amnistía Internacional que el borrador de ley presentado por el Ministerio de Educación el pasado 4 de diciembre propone la eliminación de la asignatura de Educación para la Ciudadanía. Suponiendo un retroceso inaceptable que puede hacernos volver a la situación de anteriores sistemas educativos en los que los derechos humanos no existían. Vid. Amnistía Internacional, «Sr. Wert, queremos derechos humanos en la nueva ley de educación», (2012). 
JimÉnez Moliner, A., «Medios de comunicación y hate speech en las sociedades post-totalitarias: el paradigma de Kosovo», Cuadernos Cátedra Fabrique Furió, Vol. 50/51, 2005, pp. 125-155.

LANDA GorostizA, J.-M., «Incitación al odio: evolución jurisprudencial (1995-2011) del art. 510 CP y propuesta de lege lata», Revista de Derecho Penal y Criminología, $3^{a}$ época, Vol. 7, 2012, pp. 297-346.

«La sombra en los crímenes contra la humanidad en la política anti-terrorista española: reflexiones críticas», Revista Electrónica de Ciencia Penal y Criminología, 2010.

Mason, G., «Hate crime in Australia: Are they achieving goals?», Ed. National Judicial College of Australia, 2010.

Miralles SANGro, P.-P., «Democracia, derechos humanos y constitución exigen el cierre inmediato de los centros de internamiento de extranjeros (CIES)», Revista de Derecho UNED, Vol. 10, 2012, pp. 731-742.

Moore, M., Fahrenheit 9/11, Documental, Estados Unidos, 2004.

ORganización DE Los Estados AMERICANOS. Comisión Interamericana de Derechos Humanos, «Informe anual de la Comisión Interamericana de Derechos Humanos 2008. Informe de la Relatoría Especial para la Libertad de Expresión», Volumen III, 2008.

PoKemPNER, D., «Libertad de expresión y guerra contra el terrorismo», Política Exterior, Vol. 127, 2009.

SERRANO MAÍllo, I., «El derecho a la libertad de expresión en la jurisprudencia del tribunal europeo de derechos humanos: dos casos españoles», Teoría y Realidad Constitucional, UNED, Vol. 28, 2011, pp. 579-596.

SERrano, P., Medios Violentos. Palabras e imágenes para el odio y la guerra, Ed. El Viejo Topo, Barcelona, 2008.

Soto GARcíA, M., «TEDH - Sentencia de 15.03.2011, Otegui Mondragón c. España, 2034/07 - Artículo 10 del CEDH- Libertad de Expresión - Límites - Delito de Injurias contra el Jefe del Estado - Exhortación a la Violencia y Discurso de Odio», Revista de Derecho Comunitario Europeo, Vol. 42, Madrid, 2012, pp. 575-591.

U.S. Department of Justice. Federal Bureau of Investigation, Hate Crime Data Collection Guidelines. Uniform Crime Reporting, Estados Unidos, 1999.

Van Boven, T., «Los Derechos Civiles y Políticos, en Particular las Cuestiones Relacionadas con la Tortura y la Detención». Informe del Relator Especial sobre la cuestión de la tortura, $60^{\circ}$ periodo de sesiones, E/CN. 4/2004/56/Add. 2, 2004.

TITTLE: Freedom of expression: unlimited right according to the ECHR? From hate speech to hate crime.

RESUMEN: Al inicio de la década de los ochenta y con posterioridad a al Pacto internacional de derechos civiles y políticos, algunos países anglosajones comenzaron a introducir normas especificas para combatir tipos delictivos motivados por odio e intolerancia.

Tras más de treinta años muchos autores observan mínimo el acercamiento en términos de derecho comparado, para atajar el fenómeno del 
odio, siendo acusada la falta de voluntad politica para frenar el palpable desmembramiento social que ocasiona este tipo de delitos, y los móviles que favorecen su materialización, especialmente a través del discurso del odio - «hate speech».

Muchas son las voces e instituciones que promueven limitar ese tipo de discursos extremos, sin sopesar que poniendo freno al discurso, se limitarían otros derechos fundamentales, especialmente la libertad de expresión, e incluso limitando el discurso de los intolerantes, sin desearlo daríamos paso a una sociedad suspicaz que de facto daría cobijo a radicalismos imprevistos. Pero, ¿cuáles son sus límites?

Trataremos aquí de hacer una rápida aproximación al concepto y evolución de los delitos de odio, qué discursos pueden desencadenar acciones violentas, qué respuesta están dando las instituciones europeas y qué límites están dibujando los tribunales.

PALABRAS CLAVE: Delitos de odio, discurso de odio, efecto general de silenciamiento, prejuicio, propaganda.

ABSTRACT: In the early eighties, some Anglo-Saxon countries started to introduce into their laws specific rules to combat a special type of crimes-motivated by hate and intolerance towards the victims and their groups - the so called «hate crimes». However, more than three decades later, the incorporation of this kind of laws into the different internal legislations of the countries of continental Europe is still going very slow. There is practically no political, social, legal and legislative will to put an end to the apparent social division caused by offenses and motives which favor their appearance, especially through the so called «hate speech».

There are those who suggest setting limits, without taking into account that, by forbidding the speech, they would limit other fundamental rights, especially the freedom of expression. Besides, by limiting the speech of the intolerants, we would give way to a suspicious society that de facto would host unexpected radicalism. With this study, we intend to make a quick approach to the concept and the evolution of hate crimes and evaluate what kind of offensive speech can trigger off violent actions, which answers are given by the Europeans institutions and which limits are drawn by the Courts.

KEYWORDS: Chilling effect, hate crimes, hate speech, prejudice, propaganda.

RECIBIDO: 22.09 .2014

ACEPTADO: 26.11.2014 